\title{
Designing and Computational Modeling Study of Innovative Tundish Furnitures
}

\author{
Debasish Chatterjee* \\ Department of Metallurgical and Materials Engineering, Indian Institute of Technology, Roorkee, India
}

\begin{abstract}
Slag vortexing, Reoxidation of the liquid steel from tundish open eye with high superheat casting are main causes behind many customer complains as well as high rejection of metal in integrated steel plants. In present investigation a novel stopper rod with refractory water cooled sub-chamber has been proposed. This is capable to reduce $60 \%$ skull generation and will help to reduce supeheat of liquid steel within the tundish nearly 50\%. A Novel Filter Shroud concept has been developed which will capable to generate 'No Tundish Eye' formation. This will avoid re-oxidation of liquid steel during transfer of liquid steel from ladle to tundish. Finally a modified multi reactor with argon purging technology has been proposed as a future scope of study. All design concepts are studied computationally by ANSYS FLUENT Software. All proposed works are patentable.
\end{abstract}

\section{Keywords}

Slag vortex, Stopper rod, Superheat, Tundish open eye, Re-oxidation, Filter shroud, Water cooled Sub-Chamber, Multi reactor with argon purging

\section{Introduction}

Slag entrainment, yield improvement and re-oxidation of liquid steel have got tremendous importance in recent decade. Because due to slag entrainment and re-oxidation from tundish open eye, huge amount of metal or steel have to be rejected for generation of casting defects. Contamination occurs during non-steady state transformation of liquid steel from ladle as well as tundish during teeming period [1-4]. Slag vortexing is the main cause of contamination of liquid steel during ladle drainage or ladle change over period in tundish [1]. To minimize slag vortexing many efforts have been made by modifying tundish furniture's over many decades as explored literary in few journals [1,2].

Similarly "Tundish Open Eye" is the main key for generations of detrimental inclusions in many integrated and mini steel plants around the world. Approximately $40 \%$ re-oxidation of steel melt happen during transfer of the liquid steel from ladle to tundish in continuous casting caster due to formation of tundish open eye [5]. During this re-oxidation period 30-40 ppm oxygen absorption took place in liquid steel melt [6]. Argon injection at shroud inlet enhances the formation of large size tundish open eye [7]. To reduce this effect several flow control products or tundish furniture's has been developed over the decades [8-16]. Those advanced flow control products are quite capable to reduce formation of tundish open eye to some extent. But those advanced refractory molten flow devices have limitation to reduce generation of tundish open eye and re-oxidation. It is very difficult task for mini steel plant to produce quality steel in tundish. Because the tundish size is small and residence time for floatation of inclusions are less. For that reason the tundish sub-entry nozzles are choked frequently. This happens as re-oxidation products from slag eye are not able to float within the tundish and deposited at the inner wall of the tundish sub-entry nozzle.

Therefore optimization of tundish equipment is necessary to deliver high quality liquid steel in mold continuously. In the present work a modified stopper rod as well as tundish refractory water cooled sub-chamber has been used to improve the yield ad performance of tundish by suppressing vortex formation and controlled the superheat of liquid steel. Two novel shrouds also have been designed to suppress reoxidation of liquid steel during its pouring to tundish from ladle, especially during ladle change over operation. During ladle change over period, some time is required to transfer the old ladle and open the next ladle from turret. During this period the metal level within the tundish goes down

*Corresponding author: Debasish Chatterjee, Department of Metallurgical and Materials Engineering, Indian Institute of Technology Roorkee, India

Accepted: May 16, 2019

Published online: May 18, 2019

Citation: Chatterjee D (2019) Designing and Computational Modeling Study of Innovative Tundish Furnitures. Adv Metallurg Mater Eng 2(1):61-70 

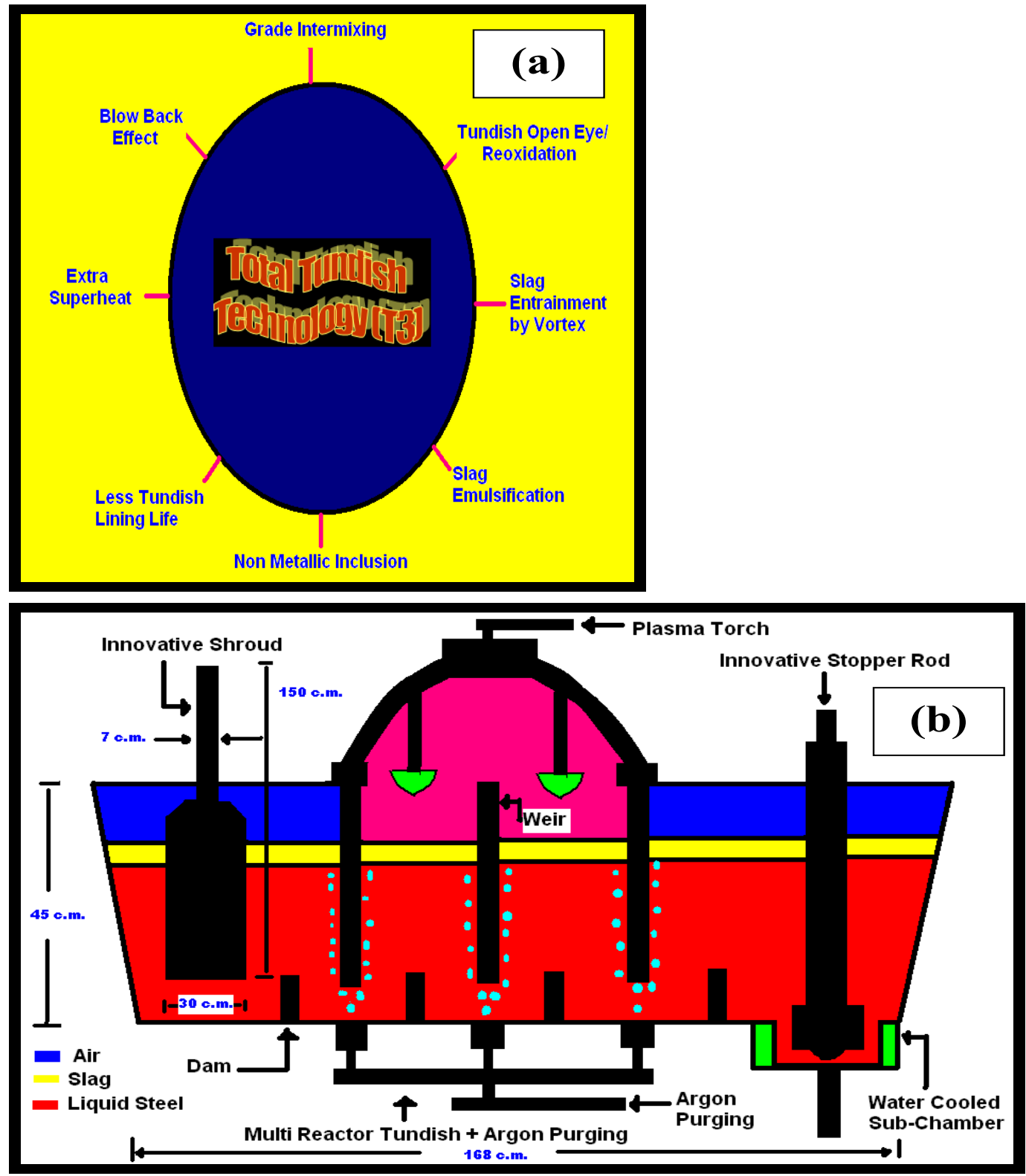

Figure 1: Schematic of a) Activities associated with total tundish technology $\left(\mathrm{T}^{3}\right)$; b) Novel total technology tundish.

to maintain the casting operation continuously. When the next ladle steel pour on the tundish, vigorous turbulences are generated which cause opening of slag cover within the tundish. This contaminates the steel by forming macro inclusion by reaction of liquid steel in open air. The present novel shroud will suppress turbulence and will improve the liquid steel quality by suppressing the opening of slag eye. VOF (Volume of Fluid) simulation has been used as a tool to predict the current investigation computationally by using ANSYS FLUENT CFD software.

\section{Present Work}

"Tundish" is an important buffer between ladle and mold. It is the heart of any integrated steel plant. The performance of the steel company is mainly dictated by the performance of Tundish. In the present work of several Novel tundish furniture's along with Multi Reactor Tundish with Argon Purging has been proposed which will act as a "Total Tundish
Technology $\left(T^{3}\right)^{\prime \prime}$ towards production of Green and Clean Steel with Sustainability.

Figure 1a describes several aspects of the total tundish technology. Figure $1 \mathrm{~b}$ is exhibiting the schematic with major dimensions of the "Total Technology Tundish". In present investigation little innovative tundish furniture have been developed which are capable to provide solution of the few aforementioned abnormalities schematically shown in Figure 1a. These abnormalities frequently happen within tundish slab caster and contaminate the liquid steel. These abnormalities decrease the yield and quality of slab or hot rolled coil production. It is anticipating that after incorporating those tundish furniture's along with MRT + AR purging tundish i.e. "Total technology tundish" will be developed which will solve all problems associated with Tundish.

To investigate the slag entrainment by vortexing phenomena a novel stopper rod as well as tundish bottom cylindri- 

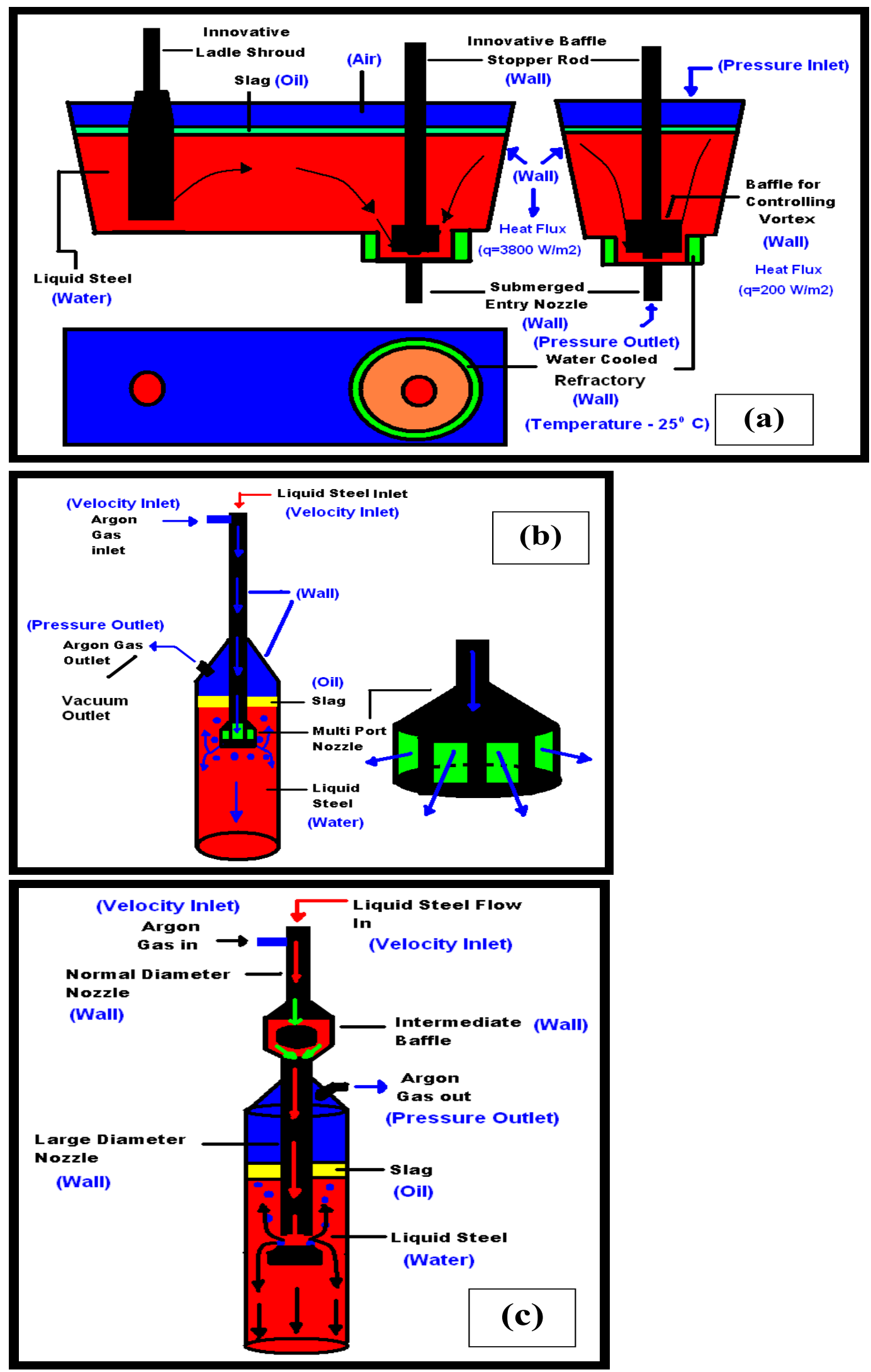

Figure 2: Schematic and boundary conditions of innovative a) Tundish and stopper rod with water cooled sub-chamber; b) Single stage filter shroud; c) Double stage filter shroud.

cal with externally water cooled refractory sub-chamber has been designed as depicted in Figure $2 a$. The outlet was shallow type which was helping to drag maximum liquid metal before slag entrainment. In the present study a novel conceptual flow control refractory products called "Filter Shroud" has been proposed. The devices have shown schematically in 
the Figure $2 \mathrm{~b}$ and Figure $2 \mathrm{c}$. When the liquid steel will pass through the nozzle, the flow will be initially diverted by an intermediate baffle and then the flow will continue through a slight large diameter nozzle. Finally liquid steel will pass through 4 port hole and will fall on the inner wall of the outer cap type baffle. Argon and Flux can be injected to capture inclusions from the liquid steel melt. This will help to reduce re-oxidation and blow back effect by eliminating conventional shroud and turbo-stop system. This will also help to avoid contamination of liquid steel during non steady state transfer of liquid steel from ladle to tundish.

\section{Experimentation/Numerical Methodology}

Computational 3D VOF (Volume of Fluid) simulation was performed by ANSYS FLUENT fluid dynamics software in the present numerical investigation. The details are explained in Table 1 [17-19].

Table 1: Summary of mathematical models used in current study [17-19].

\begin{tabular}{|c|c|c|}
\hline SI. No. & Simulation Parameters & Short Descriptions \\
\hline 1 & Model \& Solver & 3D Single precision, $1^{\text {st }}$ order Implicit, Pressure based Unsteady \\
\hline 2 & Boundary conditions & Velocity inlet, Pressure outlet, Pressure Inlet, Wall \\
\hline 3 & Energy and Viscosity & $\begin{array}{l}\text { Standard k- } € \text {, standard wall functions, C } \mu-0.09, C 1 €-1.44, C 2 €-1.92, \text { TKE Prandtl No-1, Heat Flux } \\
\text { Outer Wall - } 3800 \text { Watt/m², Heat Flux Inner Wall of Stopper Rod - } 200 \text { Watt/m² }\end{array}$ \\
\hline 4 & Volume of Fluid & Explicit, Courant No-0.25, Implicit body force \\
\hline 6 & Time step size & 0.05 sec per iteration \\
\hline 7 & Control Solution & $\begin{array}{l}\text { Pressure velocity coupling-SIMPLE, Discretization (Pressure-PRESTO,Momentum-1 } 1^{\text {st }} \text { order } \\
\text { upwind, Volume fraction- Geo-Reconstruct, Turbulent kinetic energy and dissipation - } 1^{\text {st }} \text { order } \\
\text { upwind scheme) }\end{array}$ \\
\hline 8 & Mesh Size & 0.01 meter or $10 \mathrm{~mm}$ \\
\hline 9 & Material Used & Air, water, kerosene oil, argon \\
\hline 10 & Velocity & $1 \mathrm{~meter} / \mathrm{sec}$ \\
\hline
\end{tabular}
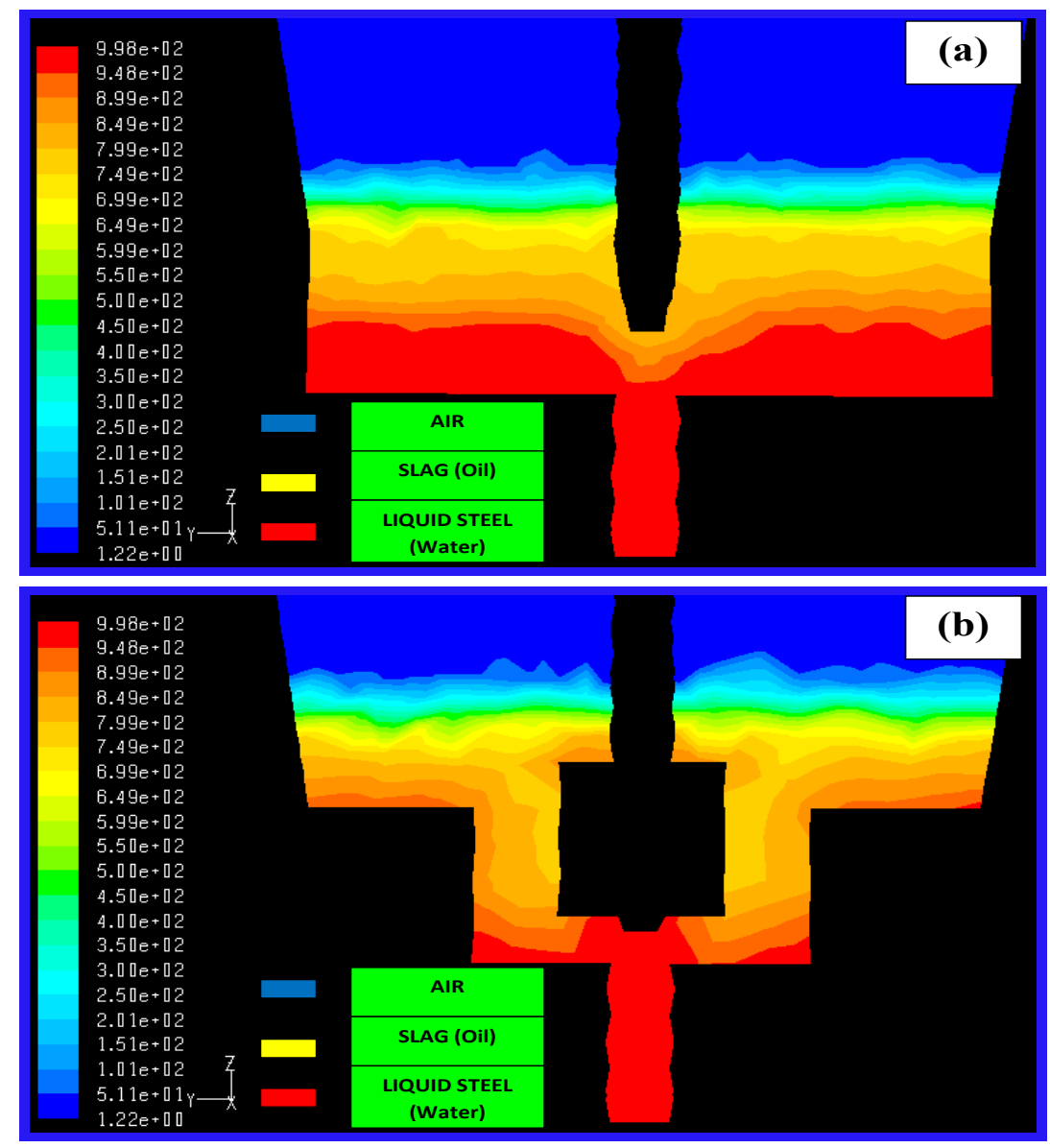

Figure 3: Multi-Phase plot of drainage of liquid with a) Conventional stopper rod system; b) Modified stopper rod with sub-chamber system. 


\section{Results \& Discussion}

\section{Formation of slag vortexing and control of superheat}

It is acknowledged well within the steel producing community that considerable amount of steel is lost as solidified skull in a tundish at the end of sequence casting [1]. Slag entrainment during drainage of liquid steel from tundish at the end of each sequence casting is the main reason behind this huge amount of metal and money loss. To minimize entrainment of slag into the mold it is customary to leave behind some residual metal in tundish during the final stage of sequence casting. Depending on the size of tundish approximately 1-7 tons metals left at the end of draining metal from tundish [1]. With the revival of steel industry and increased global demand for quality steel, steelmakers are interested to decrease such metal loss to improve the overall plant performance. There are several ways for minimizing slag entrainment during the teeming of steelmaking ladles, tundish etc. Cleaner steel, improved yield and higher productivity are all times focus of researcher. Guthrie, et al. [2] has studied 'vortexing' and non-vortexing funnels, each controlled by entirely different sets of variables. R Sankaranarayanan, et al. [2] have patented 'vortex buster' on the basis of the understanding gained from these studies, and validated in water models as well as in a 12 ton tundish [2]. The VOF (Volume of Fluid) simulation results during draining of liquid water (as the kinematic viscosity of liquid steel and water are same) have been shown in Figure 3a. The multiphase simulation results of advanced subcylindrical container with modified stopper rod system have been depicted in Figure $3 \mathrm{~b}$. In the legend the red color is showing the density of water phase, yellow color is the density of oil phase and blue color is the density of air. For conventional system the red color portion is high or it can be said that the residual metal amount is large. Nearly $5 \%$ residual metal is present. On the contrary for modified system residual metal loss is substantial low. Approximately $1.7 \%$ liquid water is present. So improvement for modified system is $\approx 60 \%$. Figure 4 a and Figure $4 \mathrm{~b}$ are showing amount of residual metal or water for both systems in metallurgical model scale tundish. It is observed that the tundish equipped with modified stopper rod and sub-chamber is showing less skull formation. But the metal loss will be more for conventional tundish due to early slag vortexing. So the modified tundish system can protect to cast product from unwanted slag infiltration during ladle change over period. Figure $5 \mathrm{a}$ and Figure $5 \mathrm{~b}$ are indicating
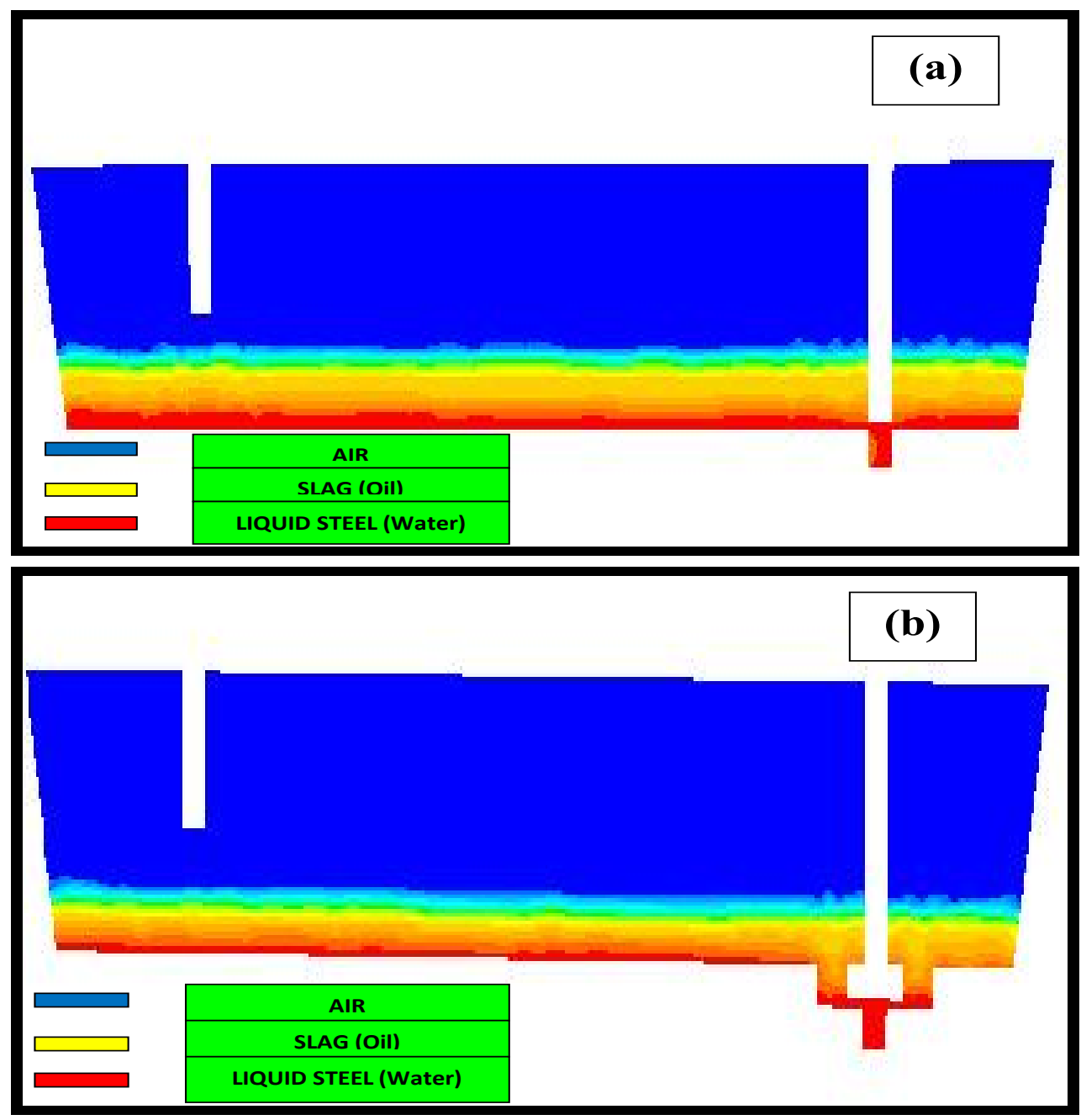

Figure 4: Multi phase plot of liquid drainage for a) Conventional system; b) Modified system. 

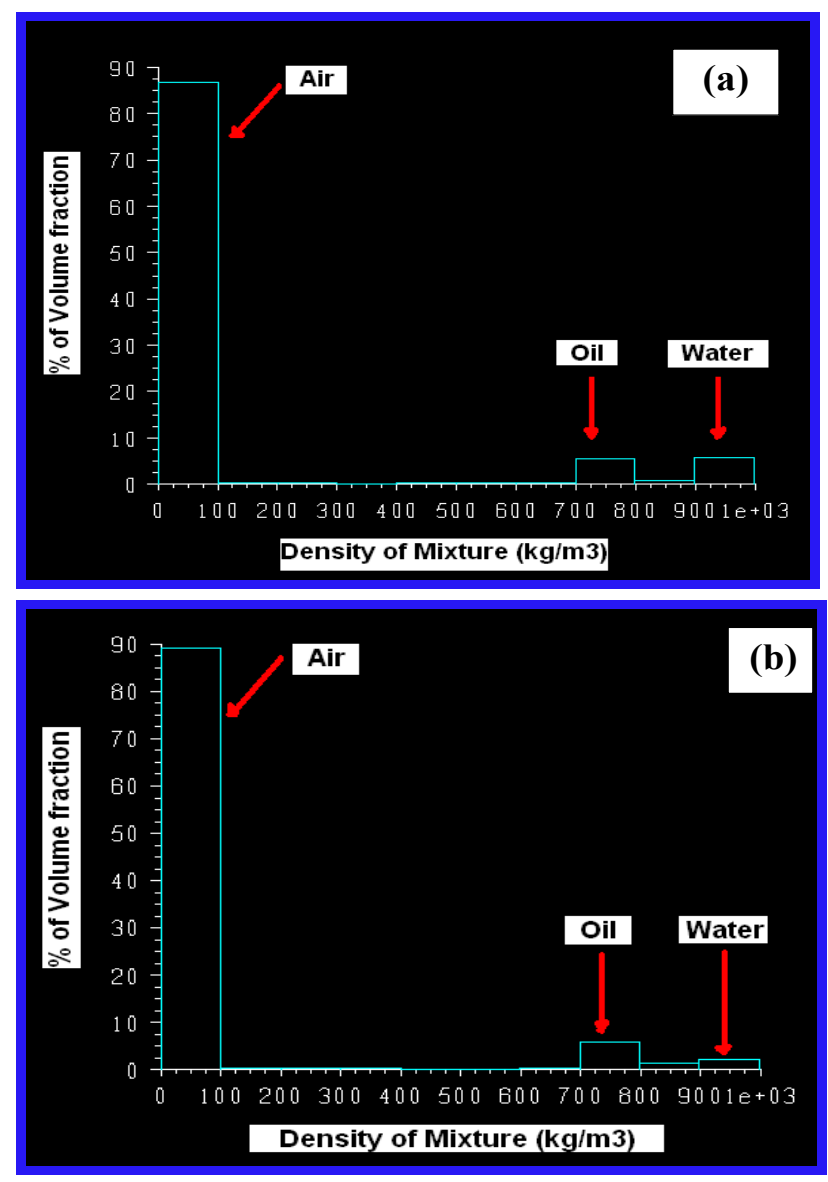

Figure 5: Histogram distribution of volume fraction water retains within the reactor for a) Normal stopper rod system; b) Modified shroud with sub-chamber system.

histogram distribution of fluid within the reactor at the last stage of draining for both systems. It is readily find that the remaining water within the modified stopper rod with subchamber system is relatively less as compare to conventional stopper rod system. Figure $6 a$ and Figure $6 \mathrm{~b}$ are showing drop of superheat for both conventional and modified systems respectively. It is observed that nearly $4{ }^{\circ} \mathrm{C}-5^{\circ} \mathrm{C}$ temperature drop for conventional system and $18{ }^{\circ} \mathrm{C}-20{ }^{\circ} \mathrm{C}$ drop for modified system. So the improvement for control superheat is $50 \%$ if initial superheat of the melt in tundish $30^{\circ} \mathrm{C}$. Figure $7 \mathrm{a}$ and Figure $7 \mathrm{~b}$ are showing line temperature plots of both the systems. It indicates that a well defined temperature drop or low superheat casting is possible for modified water cooled sub-chamber system as compared to conventional reactor. Plots in Figure $8 \mathrm{a}$ and Figure $8 \mathrm{~b}$ are exhibiting that the exit temperature of liquid for conventional system is nearly 1900 $\mathrm{K}$ where as for modified water cooled sub-chamber reactor the exit liquid temperature is around $1880 \mathrm{~K}$. Approximately $20^{\circ} \mathrm{C}$ superheat drop is expecting for innovative reactor.

\section{Formation of "Tundish Open Eye" and reoxida- tion}

From Figure 9a and Figure 9b, it is observed that large amount of oil will be dispersed and opening of slag eye takes place for conventional shroud turbo-stop combinations
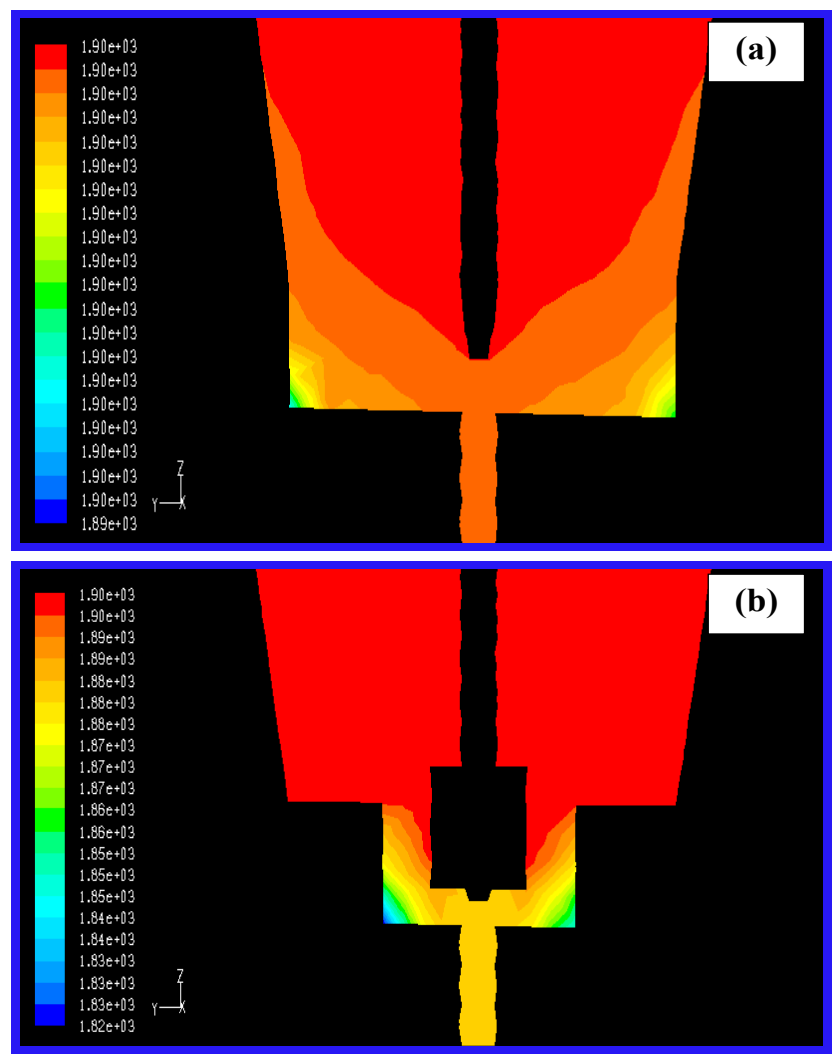

Figure 6: Temperature (in Kelvin) plot of liquid during draining from tundish for a) Conventional system; b) Modified subchamber water cooled system.
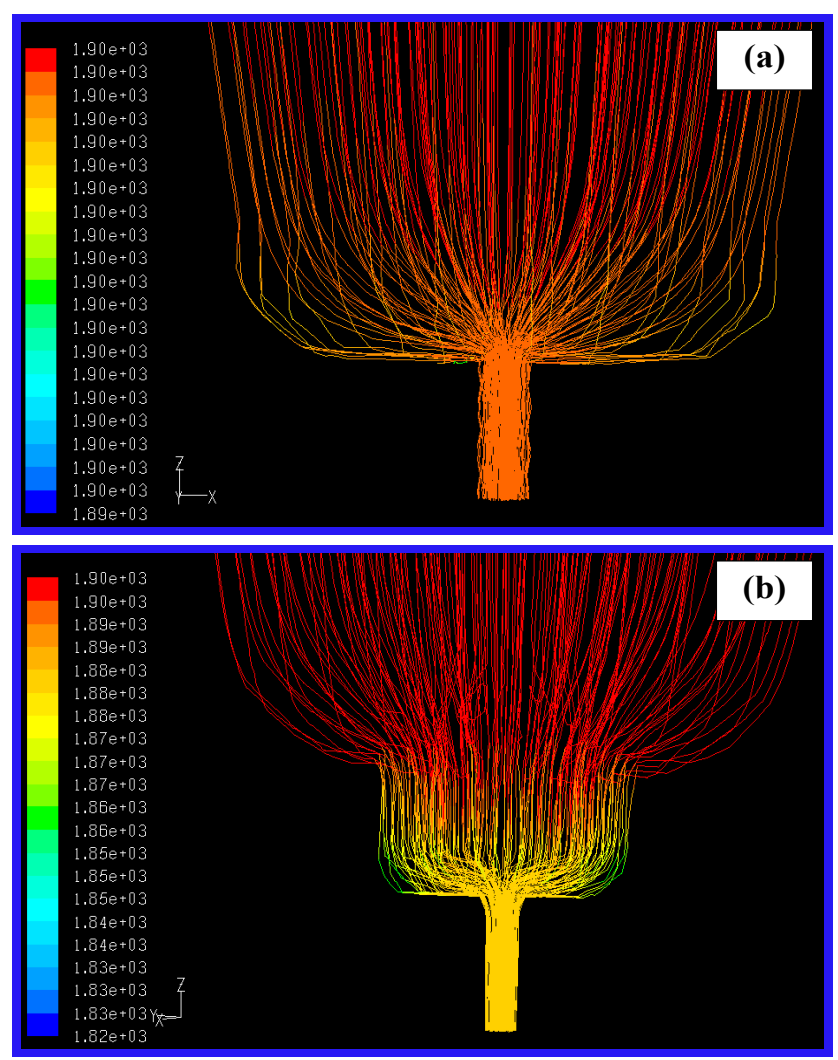

Figure 7: Temperature (in Kelvin) line plot of liquid during draining from tundish for a) Conventional system; b) Modified sub-chamber water cooled system. 
Citation: Chatterjee D (2019) Designing and Computational Modeling Study of Innovative Tundish Furnitures. Adv Metallurg Mater Eng 2(1):61-70
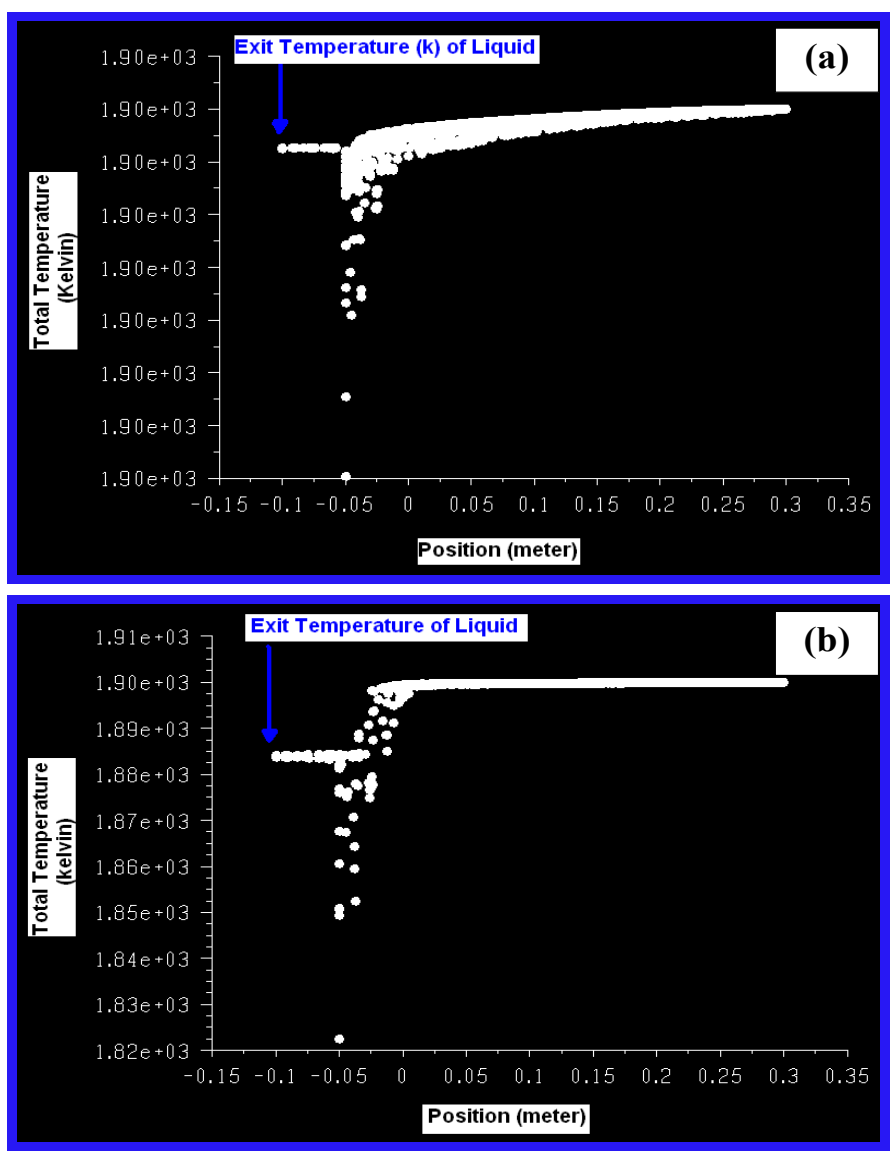

Figure 8: Temperature (in Kelvin) along the $Z$ axis Plot of liquid during draining from tundish for a) Conventional system; b) Modified sub-chamber water cooled system.
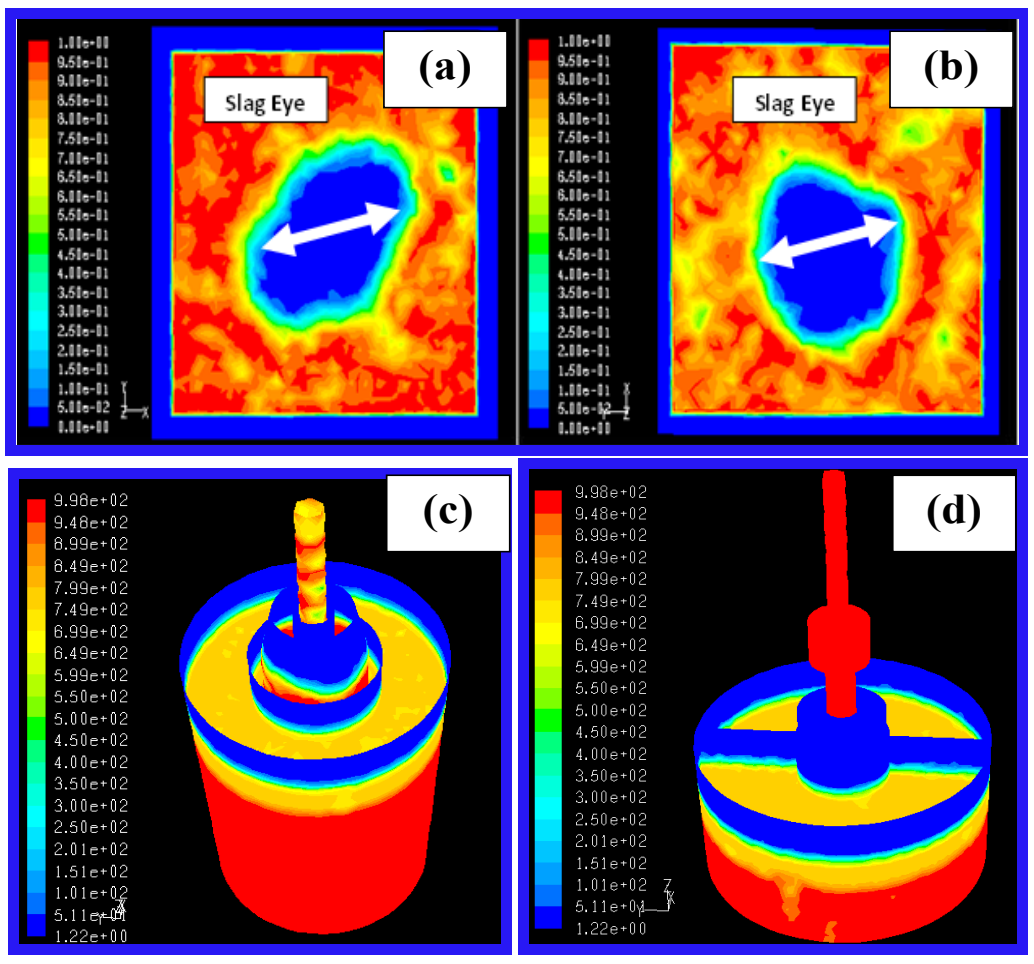

Figure 9: Formation of slag eye or tundish open eye for conventional shroud and turbo-stop system a) Without argon purging; b) With argon purging and; No slag eye formation for c) Single stage filter shroud for conventional tundish system; d) Double stage filter shroud especially low bath level tundish system. 
without and with argon purging respectively. Oil dispersion is not seeing for the case of "Filter Shroud" observed from Figure 9c and Figure 9d respectively. Approximately 95\% velocity reduction is possible for filter type novel shroud. This high velocity reduction is possible as the velocity drop takes place initially at the intermediate baffle and again pour in a large size diameter nozzle than the initial size of the inlet nozzle as well as finally velocity break happens due to impingement of the fluid in an inner wall of a cap type baffle attached with the novel shroud. Inclusions which are generated from re-oxidations create voids, laps, pipe lamination, slivers, line defects on the hot rolled as well as
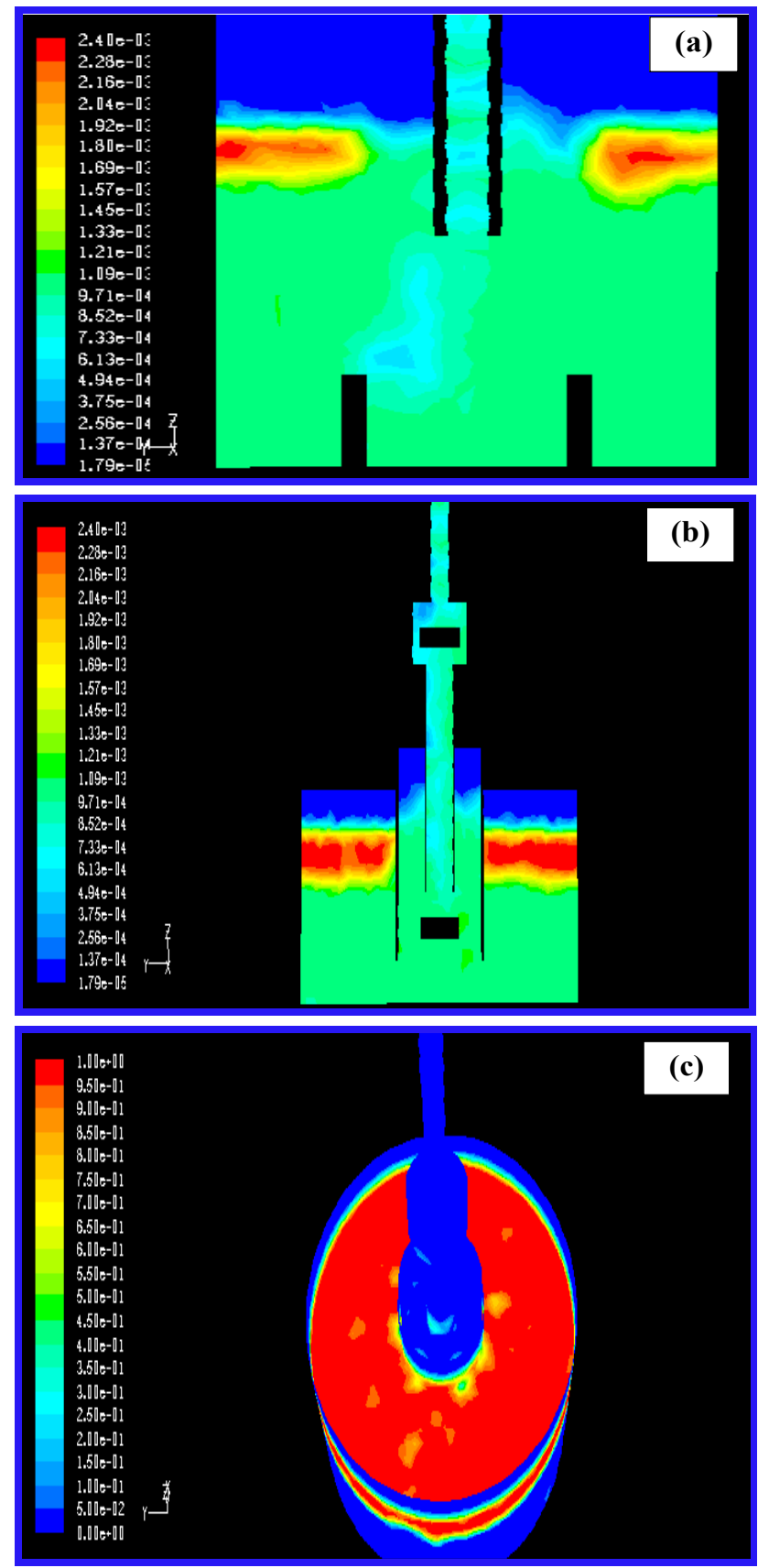

Figure 10: Formation of slag eye or tundish open eye for conventional shroud and turbo-stop system a) With argon purging; $b, c)$ No slag eye formation for double stage filter shroud especially low bath level tundish system. cold rolled product $[20,21]$. There were some confusion among the metallurgists and plant operators that the tundish open eye has a chance to be covered by argon gas which can inhibit re-oxidation. But recent investigations of few researchers reveal that tundish open eye or slag eye is the main source of re-oxidation of liquid steel during transfer of metal from ladle to tundish [22]. From 1975 to 2010 several United States of America (USA) patents have been applied by researchers regarding the development of turbo-stop and shroud to control turbulence within the tundish to reduce re-oxidation of steel melt from exposed eye [23-25]. But still now it is not possible for the metallurgists, researchers and plat operators to control the turbulence drastically so that re-oxidation from open eye as well emulsifications from turbulence during ladle change operations can be controlled significantly. For that reason, clean steel production is very difficult task for plant operator's especially mini steel plants where for making special grade steel a small two strand tundish are frequently used. Figure $9 \mathrm{a}$ and Figure $9 \mathrm{~b}$ are depicting the formation of large size tundish open eye in case of conventional shroud and turbo-stop combination without and with argon purging respectively. Similarly Figure 9c and Figure 9d are showing 'NO SLAG EYE' or 'NO TUNDISH OPEN EYE' condition for the case of innovative 'FILTER SHROUD' during the presence of high level liquid and low level liquid within the bath respectively. So it can be said that the present innovative molten steel flow control refractory is quiet capable to reduce the formation of slag eye or tundish open eye in a substantial amount. This product will also help to eliminate re-oxidation of the steel melt within tundish as well as will help to eliminate emulsification.

Figure 10a, Figure $10 b$ and Figure 10c are multiphase plots of conventional shroud and innovative shroud systems. It is observed from those figures that a large tundish open eye is formed for conventional shroud and turbo-stop system as depicted in the Figure 10a. Similarly for novel shroud i.e. for double stage Filter Shroud no tundish open eye condition is found as observed from Figure 10b and Figure 10c respectively. So it can be stated that the new or novel steel flow control device is quite capable to control re-oxidation as well as it helps to improve the safety of the tundish operators and technicians by suppressing blow back effect during transfer of very high temperature liquid steel from ladle to tundish at the initial stage of sequence casting. Not only that it will also help to reduce emulsification within tundish during non-steady stage operation of tundish and will help to avoid contamination of liquid steel from tundish covering compound by eliminating emulsifications.

\section{Future Study}

Multi Reactor with argon purging is a novel concept towards production of clean steel with less grade mixing in continuous slab casting tundish [26]. In future the author wants to modify that concept as embodied in the Figure 11. Numerical simulation as well as physical modeling approach can be used for that modified tundish. The all works mentioned here are novel in nature. After computational, physical modeling and plant trial investigation the author wants to make patent of those novel technologies. 


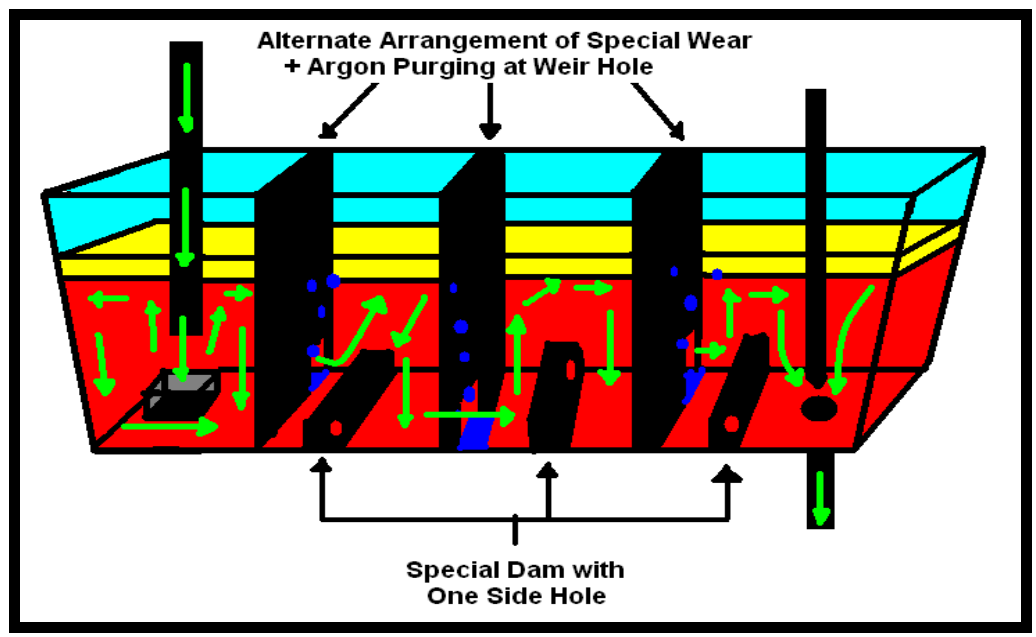

Figure 11: Schematic of modified MRT-ARGON purging tundish for future study.

\section{Conclusions}

From the above study it is observed that the modified stopper rod with water cooled sub-chamber can be used to reduce skull formation within the tundish during draining at the last stage of every sequence of continuous casting. It will not only help infiltration of slag within the mold due to vortex formation and at the same time it will help to control over superheat within the tundish. High superheat casting is responsible for formation of detrimental centerline crack and segregation. It is also observed that $60 \%$ reduction of skull formation and $50 \%$ reduction of superheat are possible to achieve in the modified tundish technologies. Single or double stage Filter Shrouds are highly efficient to control the pouring velocity of liquid steel to tundish from ladle. Maximum 95\% reduction of velocity is possible for this type of shroud. No slag eye condition is possible to reach for this type of shroud. Modified MRT + ARGON purging tundish can be studied in future to make a better efficient novel tundish system. Patent can be filed after numerical, physical modeling and plant trial investigations.

\section{Acknowledgements}

The author is highly grateful to Department of Metallurgical and Materials Engineering, Indian Institute of Technology Roorkee.

\section{References}

1. D Mazumdar, S Bagui, J Dutta, et al. (2011) Reduction of tundish skull: Physical modeling and plant scale investigations. IIM Metal News 14: 7-10.

2. R Sankaranarayanan, RIL Guthrie (2002) Slag entraining vortexing funnel formation during ladle teeming: Similarity criteria and scale-up relationships. Ironmaking and Steelmaking 29: 147-153.

3. O Davila, RD Morales, L Gracia-Demedices (2006) Mathematical simulation of fluid dynamics during steel draining operations from a ladle. Metallurgical and Materials Transactions B 37: 71-87.

4. K Kuwana, MI Hassan, PK Singh, et al. (2008) Scale-Model experiment and numerical simulation of a steel teeming process. 23: 407-412.
5. Y Sahai, T Emi (2007) Tundish Technology for Clean Steel Production. World Scientific Publishing Co Pte Ltd.

6. S Chatterjee, K Chattopadhyay (2016) Tundish open eye formation in inert gas-shrouded tundishes: A macroscopic model from first principles. Metallurgical and Materials Transactions B 47: 3099-3114.

7. T Bhattacharya, AJ Brown, CM Muller, et al. (2016) AISTech proceedings. Association for iron \& steel technology ${ }^{\circledR}$. Pittsburg Pennsylvania USA.

8. D Chatterjee (2017) "Vacuum Shroud (VS)"- A green flow control device (FCD) towards replacement of "Turbo Stop" in tundish metallurgy. American Journal of Mining and Metallurgy 4: 1-31.

9. H Odenthal, R Bolling, H Pfeifer, et al. (2001) Mechanism of fluid flow in a continuous casting tundish with different turbo stoppers. Steel Research Int 72: 466-476.

10. J Zhang, J Li, Y Yan, et al. (2016) A comparative study of fluid flow and mass transfer in a trumpet-shaped ladle shroud using large eddy simulation. Metallurgical and Materials Transactions B 47: 495-507.

11. K Morales-Higa, RIL Guthrie, M Isac, et al. (2013) Ladle shroud as a flow control device for tundish operations. Metallurgical and Materials Transactions 44: 63-79.

12. J Madias, DM Ferreyra, R Villoria, et al. (1999) Design and plant experience using an advanced pouring box to receive and distribute the steel in a six strand tundish. ISIJ International 39: 787-794.

13. GS Diaz, RD Morales, JP Ramos, et al. (2004) Analysis of fluid flow turbulence in tundishes fed by a swirling ladle shroud. ISIJ International 44: 1024-1032.

14. J Zhang, S Yang, J Li, et al. (2015) Large eddy simulation on flow structure in a dissipative ladle shroud and a tundish. ISIJ International 55: 1684-1692.

15. D Chatterjee (2012) Designing of a novel shroud for improving the quality of steel in tundish. Advanced Materials Research 585: 359-363.

16. R Schwarze, D Haubold, C Kratzsch (2015) Numerical study of effects of pour box design on tundish flow characteristics. Ironmaking and Steelmaking 42: 148-153. 

2(1):61-70

17. Wolfgang Rodi (1984) Turbulence models and their application in hydraulics - A state of the art review, Netherlands 1-104.

18. Sujay Pandit Patil, Dipak Mazumdar (2007) Prediction of strand superheat in continuous casting: Modeling and industrial scale measurements in steelmaking tundish systems. Steel Grips 5: 119-126.

19. Ansys Fluent 6.3 User's Guide, Lebanon, (2006), p. 1/2501.

20. L Zhang, BG Thomas (2006) State of the art in the control of inclusions during steel ingot casting. Metallurgical and Materials Transactions B 37: 733-761.
21. L Zhang, BG Thomas (2003) State of the art in evaluation and control of steel cleanliness. ISIJ International 43: 271-291.

22. S Chatterjee, D Li, J Leung, et al. (2017) 9th ECCC European Continuous Casting Conference, Austria Center, Vienna.

23. M Soofi: U.S. patent No - 5072916, (December 1991).

24. K J Saylor: U.S. Patent No - 5358551, (October 1994).

25. G Hohenbichler, G Eckerstorfer, M Brummayer: U.S. Patent No US 7789123 B2, (September 2010).

26. D Chatterjee (2016) A Novel Tundish for Single Strand Slab Casting. J Inst Eng India Ser D 97: 105-112.

DOI: $10.36959 / 508 / 397$

Copyright: (C) 2019 Chatterjee D. This is an open-access article distributed under the terms of the Creative Commons Attribution License, which permits unrestricted use, distribution, and reproduction in any medium, provided the original author and source are credited. 